\title{
Material Flow Analysis of Plastic Waste and Paper Waste from Waste Banks in Surabaya
}

\author{
Amar Addinsyah, I. Dewa Ayu Agung Warmadewanthi* \\ Surabaya, Indonesia \\ Email address: \\ a.addinsyah@gmail.com (A. Addinsyah),warmaputu@gmail.com (I. D. A. A. Warmadewanthi) \\ ${ }^{*}$ Corresponding author
}

Department of Environmental Engineering, Faculty of Civil, Planning, and Geo Engineering, Tenth of November Institute of Technology,

\section{To cite this article:}

Amar Addinsyah, I. Dewa Ayu Agung Warmadewanthi. Material Flow Analysis of Plastic Waste and Paper Waste from Waste Banks in Surabaya. American Journal of Environmental Protection. Vol. 9, No. 5, 2020, pp. 97-101. doi: 10.11648/j.ajep.20200905.11

Received: August 17, 2020; Accepted: August 31, 2020; Published: September 14, 2020

\begin{abstract}
Waste banks has been long being a part of waste management in Surabaya. Waste banks also plays a role in implementing the circular economy concept by collecting and reselling waste from household. The waste that has been collected from the waste banks were sold to the Main Waste Bank and small scrap dealers. This study aims to identify the material flows of plastic wastes and paper wastes from the waste bank to the recycling industry. The methods used for data collection includes survey and interview to the management of waste banks, management of the main waste bank, waste collectors, and management of the industries involved. The identification of material flows of plastic wastes and paper wastes from the waste banks to the recycling industries was done using the material flow analysis method. The material flow of the waste bank in the Central Surabaya region shown that the generation of waste generated at the waste bank was $34,815.1 \mathrm{~kg}$ per year. The waste was distributed to the main waste bank and waste collectors before finally being sold to the recycling industry and out of the system as plastic products at $13,041.45 \mathrm{~kg}$ per year and paper products at $20,311.14 \mathrm{~kg}$ per year.
\end{abstract}

Keywords: Material Flow Analysis, Paper Waste, Plastic Waste, Recycle, Solid Waste, SWOT, Waste Bank

\section{Introduction}

Waste management has become a complex problem in developing country. The increase in population and industrialization play a big role in the increase of solid waste. In city with high population density, household waste has become quite a problem. Surabaya as one of the highly populated city in Indonesia face similar challenge. The population in Surabaya generated $3,982.25 \mathrm{~m}^{3}$ of solid waste every day $[5,11]$.

In Indonesia waste management was regulated by the Act No. 18/2008. Mentioned by Article 29 was a prohibition of waste management which will cause pollution, illegal dumping, and open burning. Government Regulation No. $81 / 2012$ also stated the importance of reduce, reuse, and recycle (3R) of household waste. The importance of $3 \mathrm{R}$ also stated in Regulation of Minister of Environment No 13/2012 about guidelines for 3R implementation through the waste bank. Based on these regulations, waste bank was seen as a suitable alternative in managing household waste in
Surabaya.

Waste bank is a social engineering activity that teaches people to sort waste and raise public awareness in managing waste wisely and in turn reduces waste transported to landfills [12]. The implementation of a waste bank is the initial momentum to foster community collective awareness to start sorting, recycling, and utilizing waste because waste has a fairly good selling value, so that environmentally friendly waste management becomes Indonesia's new culture.

The waste bank has several benefits for humans and the environment, such as making the environment cleaner, making people aware of the importance of cleanliness, and making waste into economic goods. A waste bank manage waste by buying waste in the form of savings similar to the banking system. Waste bank operates in a similar way to a bank where people can save and withdraw money from the sale of the waste. People can at any time withdraw money from their savings when they have accumulated a lot of savings. The rewards given to customers are not only in the form of money, but some are in the form of daily items such as sugar, soap, oil and rice, 
and even mobile phone credit [7, 10, 15].

There are several types of rubbish deposited into the waste bank, for example: organic waste, such as vegetable scraps or food scraps; and non-organic such as plastics, iron, and others. The waste bank sets the purchase price for each type of waste.

Waste that can still be recycled such as organic materials can be used for compost or biogas. Meanwhile, non-organic materials are recycled into various kinds of furniture such as bags, sandals, and others. There are several waste banks that have their own processing equipment such as composter, plastic pellet maker, etc., so they can sell recycled items at a higher price. However, there are also waste banks that only function as suppliers for collectors. They work together with collectors who routinely collect economical waste for recycling.

Waste bank in its implementation can reduce the high number of waste in the community and in landfills. As a result, the volume of waste in the community and landfill can be reduced. Waste bank operation also follows the principles contained in Regulation No. 18/2008 concerning waste management, which has the $3 \mathrm{R}$ principle. The independent waste management program through the waste bank is currently an alternative solution for the government and society, to reduce the ever-increasing volume of waste that is getting out of control.

The composition of household waste in Surabaya mostly dominated by food waste, plastic, and paper [6]. Food waste has little monetary value and generally disposed to landfill or composted. Waste bank mostly received plastic and paper waste from the household. Plastic wastes were generated in the form of wrapping plastic, plastic bottle, food packaging, and other form of plastic. Paper wastes were generated in the form of cardboard, old newspaper, office paper, and other form of paper waste.

Waste bank in Surabaya shows a decline in activity. The decline was indicated by the decrease in number of active waste banks in Surabaya. There are many reason for the decline with most notable reasons are shortage of manpower and failure in management. The lack of government oversight made the problems goes unnoticed for years. Thus, this study aim to identify the flow of plastic and paper waste from the waste bank The result of this study will be used to support the government and stakeholders in making the necessary decision to improve the management of solid waste in Surabaya.

\section{Materials and Methods}

\subsection{Study Area}

The study was conducted in Central Surabaya region. The total population in Central Surabaya in 2019 was 374,295 and total area of $14.78 \mathrm{~km}^{2}$ [14] which is divided into 4 districts. Central Surabaya comprises of residential, educational, and government offices area.

Central Surabaya has waste generation of $0.35 \mathrm{~kg} /$ person every day. A total of 65 waste banks were registered in Central Surabaya with only 24 units among them are active. The waste banks activities have not been integrated into a formal sector of waste management. The waste banks are managed by community or individuals. They exchange recyclable waste into money in the form of savings which is similar to the system commonly used by banks $[1,4]$.

\subsection{Data Collection}

The data collection stage of this study was done by field observation and interviews. Field observation was carried out in all 24 units of active waste bank in Central Surabaya. Interviews was carried out with manager of waste banks, manager of Main Waste Bank, informal waste buyer, and manager of recycling plants. The data collection was conducted to cover the background information, type of waste that were accepted, activities and processes related to the treatment of the waste, and input and output from each parties involved.

\subsection{Construction of Material Flow Analysis (MFA)}

Material flow analysis is one of the main tools in industrial ecology when considering sustainability issues in metropolitan areas. MFA is a systematic assessment of the flow of material circulating through several processes in a system with restricted boundary. MFA follow the law of conservation of mass (and, when using MFA-type analysis to examine energy systems, energy conservation) and, in simple terms, is the accounting of goods and substances through a system. Material Flow Analysis has demonstrated its potential to evaluate the interaction between material flow, economy and the environment. Material Flow Analysis helps in deepening the efficient use of resources, recycling waste and conserving energy. This study uses material flow analysis at a city scale; a method for checking a given system by counting all its material inputs, material accumulations and their results within the system boundary $[2,8]$.

The construction of MFA was done by STAN software developed by Vienna University of Technology in cooperation with INKA software. The STAN software is a tool to construct MFA and has been used to construct material balance in regional and plant level [9. The construction steps of MFA using STAN software are determining the type of material, determining the processes involved, and determining the direction of the material flows [3, 9].

\section{Result and Discussion}

\subsection{Waste Bank}

The waste bank is a unit whose function is to collect waste from the community for later resale or recycling. In the waste bank, customers sell the garbage collected from the household into money which is recorded in the waste bank's books. The waste is weighed and recorded by the waste bank manager. The weighed and recorded waste was then collected and sold to the Main Waste Bank or informal waste buyer.

The waste bank receives $38,415.5 \mathrm{~kg}$ of waste annually. A total of $17,759.31 \mathrm{~kg}$ of waste was sold to the Main Waste Bank and a total of $20,289.95 \mathrm{~kg}$ of waste is sold to collectors. A small amount of $365.84 \mathrm{~kg}$ of plastic waste was recycled 
into valuable furniture for sale. The composition of waste in the waste bank can be seen in Figure 1.

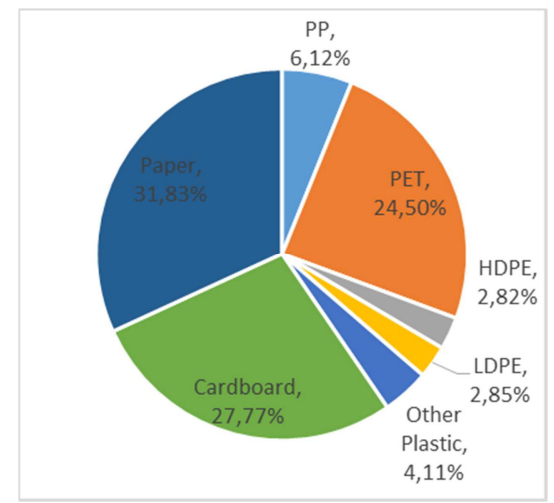

Figure 1. Waste composition in waste bank.

\subsection{Main Waste Bank}

The Main Waste Bank is a unit that functions to collect waste from both individual and collective sources for resale. The incoming waste is sorted by type. Sorting is carried out to ascertain whether the waste has been sorted according to its type and to separate waste that has a selling value from its impurity. The results of the interview show that the sorting results can produce waste residue of $1 \%$ of the waste that enters the main waste bank. The sorted waste is then weighed per type of waste and recorded. The Main Waste Bank pays an amount of money to the waste bank according to the weighing and recording results. The sorted, weighed, and recorded waste is then sold to processing industries, collectors and other buyer as needed.

Main Waste Bank received 17,759.31 kg of waste from the waste bank. $474.17 \mathrm{~kg}$ of bottle cap HDPE plastic waste were sold to the local art workshop to be used as art material. A total of 2,063.63 kg of PP waste, $831.14 \mathrm{~kg}$ of LDPE waste, $618.02 \mathrm{~kg}$ of other plastic waste, $5,274.51 \mathrm{~kg}$ of cardboard waste, and $4,828.76$ of paper waste were sold to large-scale enterprise. A total of $3,491.48 \mathrm{~kg}$ of PET plastic waste was sold to the recycling plant. The Main Waste Bank activities generates $177.59 \mathrm{~kg}$ of residual waste that is disposed to the landfill. The composition of waste in the Main Waste Bank can be seen in Figure 2.

\subsection{Informal Waste Buyer}

There are two types of informal waste buyer, small scrap dealer and large-scale enterprise [13]. Small scrap dealer bought waste collected by waste banks, scavenger, and individual. The type of waste bought by small scrap dealer include almost all type of recyclable waste. Small scrap dealer do not sell the waste directly to recycling plant because the amount of waste collected is relatively so that the shipping costs are not comparable with the sales of waste. Small scrap dealer sell the collected waste to large-scale enterprise in bulk. Large-scale enterprise bought waste collected by the Main Waste Bank and small scrap dealers. Some large-scale enterprise performs cleaning and shredding of the collected waste before it is resold which generated residual waste. Every large-scale enterprise usually deals with only one type of waste, either plastic only or paper only. Large-scale enterprise sell the waste they bought in large bulk to recycling plant.

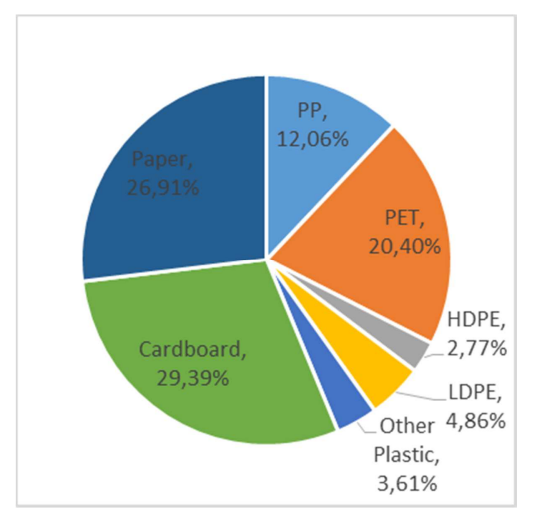

Figure 2. Waste composition in main waste bank.

Small scrap dealer received $20,289.95 \mathrm{~kg}$ of waste from the waste bank consisting of $164.35 \mathrm{~kg}$ of PP waste, $5,711.62$ $\mathrm{kg}$ of PET waste, $582.32 \mathrm{~kg}$ of HDPE waste, $215.07 \mathrm{~kg}$ of LDPE waste, 923.19 other plastic waste, $5,340.31 \mathrm{~kg}$ of cardboard waste, and $7,353.08 \mathrm{~kg}$ of paper waste. The collected waste in small scrap dealer was sold to large-scale enterprise. The large-scale enterprise received 2,063.63 kg of PP waste, $831.14 \mathrm{~kg}$ of LDPE waste, 618.02 other plastic waste, $5,274.51 \mathrm{~kg}$ of cardboard waste, and 4,828.76 of paper waste from the Main Waste Bank. The large-scale enterprise sold 2,204.82 $\mathrm{kg}$ of PP waste, $5,653.93 \mathrm{~kg}$ of PET waste, 577.40 HDPE waste, 1,036.31 LDPE waste, 1,526.56 other plastic waste, $10,508.24 \mathrm{~kg}$ of cardboard waste, and $12,059.69 \mathrm{~kg}$ of paper waste to recycling plant. A total of $339.06 \mathrm{~kg}$ of residual waste is disposed to the landfill. The composition of waste in the large-scale enterprise can be seen in Figure 3.

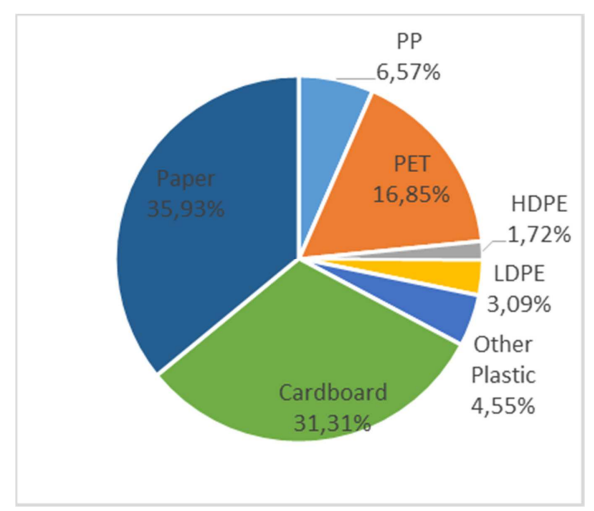

Figure 3. Waste composition in large-scale enterprise.

\subsection{Recycling Plant}

The recycling plant is the party whose function is to buy waste, process waste, and sell products from waste processing in the industry. There are two types of recycling plant, plastic recycling plant and paper recycling plant. The plastic 
recycling plant performs sorting, shredding, and washing in its recycling process. The plastic recycling plant generally sells its products as plastic seed. The paper recycling plant performs shredding, pulping, printing, and drying in its recycling process. The paper recycling plant generally sells its products as recycled paper.

Recycling plants received $3,491.48 \mathrm{~kg}$ of PET plastic waste came from the Main Waste Bank. 2,204.82 kg of PP waste, 5,653.93 $\mathrm{kg}$ of PET waste, 577.40 HDPE waste, 1,036.31 LDPE waste, 1,526.56 other plastic waste, $10,508.24 \mathrm{~kg}$ of cardboard waste, and $12,059.69 \mathrm{~kg}$ of paper waste were received from large-scale enterprise. A total of $13,041.45 \mathrm{~kg}$ of recycled plastic and $20,311.14 \mathrm{~kg}$ of recycled paper were sold as processed products. The recycling process generated $3,705.84 \mathrm{~kg}$ of residual waste as reject in the processing process. The composition of waste in the recycling plant can be seen in Figure 4.

\subsection{Material Flow Analysis (MFA)}

The waste generation, waste composition, and information related process from each parties involved is used as input in STAN software. The waste generation data is used to determine the mass flow. The waste composition data is used to calculate the transfer coefficient. The process data is used to determine the mass flow direction.

The amount of waste sold to the Main Waste Bank is smaller than the amount sold to small scrap dealer. The result of the interview show that only 3 of 24 waste banks in Central Surabaya sold their collected waste to Main Waste Bank which indicate that the waste banks that sold their waste to the Main
Waste Bank collected more waste in average that the waste banks that sold their waste to small scrap dealer. It shows that while the informal buyer can persuade more waste bank to sell their waste to them, they lack the ability to motivate the waste bank to collect more waste from their customer. The Main Waste Bank as a formal buyer stipulate a stricter rules to their affiliated waste banks. While it might become an inconvenience, this has succeeded in compelling the waste banks to be more active in collecting waste from their customers. Large-scale enterprise sold more type of waste to recycling plant than Main Waste Bank. The Main Waste Bank sold most of their waste to large-scale enterprise. It shows that Main Waste Bank as a formal sector player has difficulty in finding more potential buyer from recycling plant which become a challenge to integrate the waste bank system into a more formal waste management system.

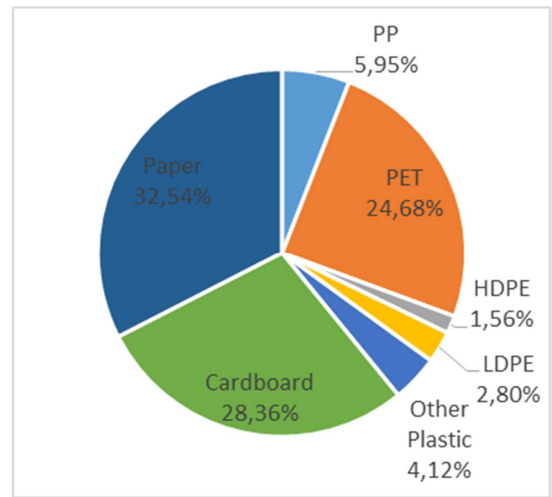

Figure 4. Waste composition in recycling plant.

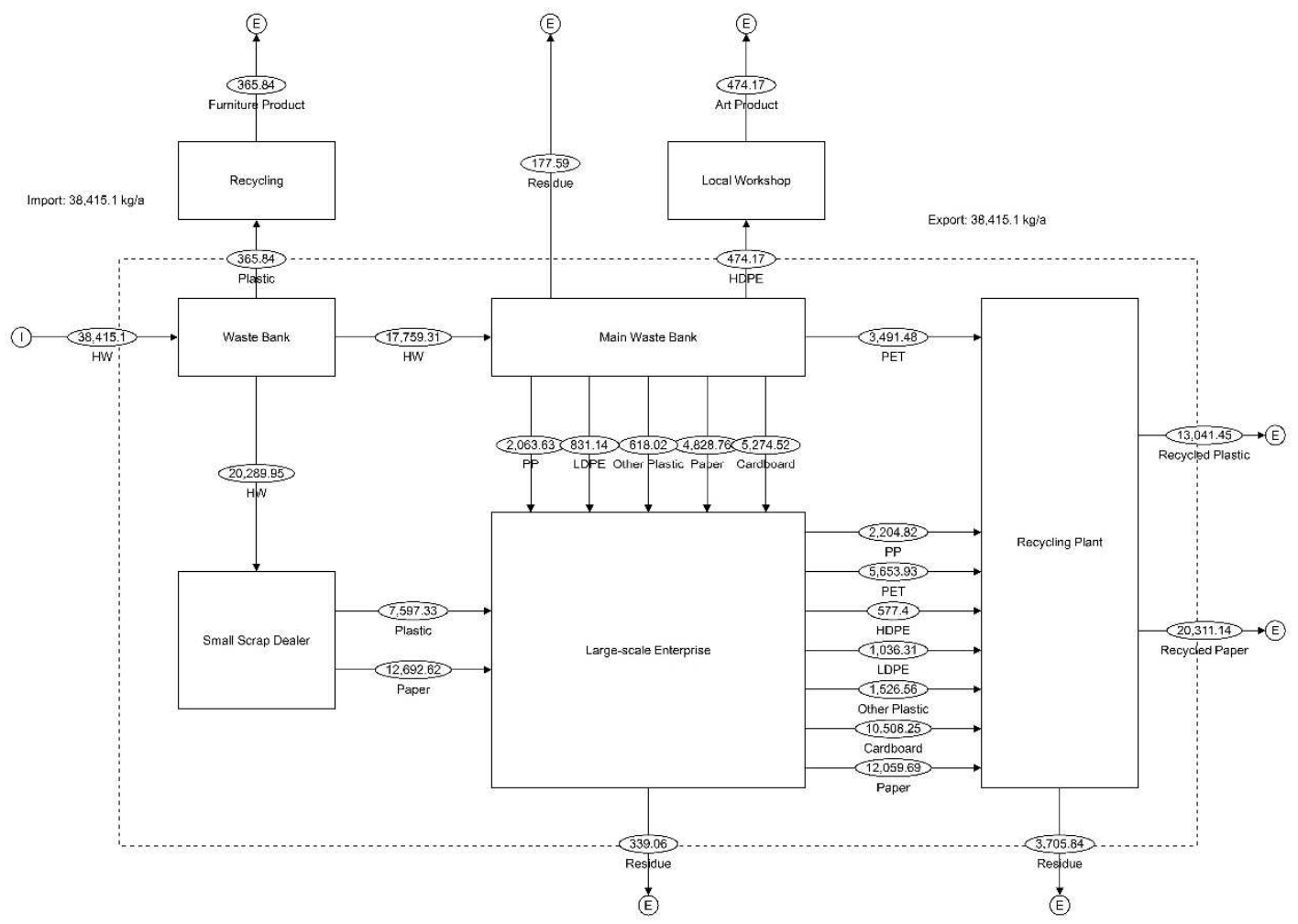

Figure 5. Material flow analysis of waste bank system. 
Main Waste bank and large-scale enterprise produced residue from the rejected waste that has been collected. Rejected waste usually contains impurities or pollutant. From interview with Main Waste Bank management and large-scale enterprise owner residue from rejected waste commonly amounted to $1 \%$ of total collected waste. Recycling plant also produced residue from rejected waste. Rejected waste from recycling plant amounted to $10 \%$ of collected waste in recycling plant. Recycling plant have bigger amount of rejected waste because the production line in recycling plan requires much more control in raw material quality. Rejected waste in plastic recycling plant includes biodegradable plastic and calcium mixed plastic. Rejected waste in paper recycling plant includes paper and cardboard that contains adhesive or clip.

The result of material flow analysis shows that from $38,415.5 \mathrm{~kg} /$ year households waste that had been circulated from waste bank to recycling plant, only 4,222.5 kg/year residue has been produced. The recovery factor was amounted to $89 \%$. The recovery factor can be considered good compared to typical recovery factor of plastic and paper waste which amounted to $50 \%$ [16].

\section{Conclusion}

The waste bank system in Central Surabaya can produce $33.9 \%$ of recycled plastic, $52.9 \%$ of recycled paper with $11.0 \%$ from the total amount of waste collected in waste bank. A small amount of waste was sold before entering the recycling plan. $1,0 \%$ of waste was sold by waste bank in the form of furniture product made of plastic waste and 1,2\% waste was sold by Main Waste Bank as material for local art workshop.

The recovery factor indicates that the waste bank system is a reliable method to be used in household waste management. According to the manager of the recycling plant, the recycling industry has a high demand of recyclable waste. Some recycling plants did not reach their maximum production capacity with some even has to put more effort to keep their production line going. These situations shows that besides being a reliable method in reducing waste, waste banks also have the potential to play an important role in circular economy in Surabaya. The implementation of circular economy will establish a more sustainable consumption pattern which is in line with SDGs 2030.

The waste bank however face a tough challenge. Community participation as the core of waste bank operation shows a decline in activity. Household waste sorting is only implemented by $47.7 \%$. The reasons for the low rating in household waste sorting are mainly because of lack of time, lazyness, and not knowing the procedure of sorting the household waste [6]. Since community participation is the core of the waste bank operation, it is necessary to improve the community participation activity in order to optimize the operation of waste bank in Surabaya.

\section{References}

[1] Ayuningtyas, T. and Trihadiningrum, Y. (2010). Study of Waste Management in Bubutan District. Tenth of November Institute of Technology. Surabaya.

[2] Brunner, P. H. and Rechberger, H. (2003) Practical handbook of material flow analysis: p 320. Lewis Publishers CRC Press LLC. Florida.

[3] Cencic, O. and H. Rechberger. (2008). Material flow analysis with software STAN. Journal of Environmental Engineering and Management 18 (1): 3-7.

[4] Department of Cleanliness. (2020). Waste Bank Data in Surabaya.

[5] Dhokhikah, Y. and Trihadiningrum, Y., (2012). Solid waste management in Asian developing countries: challenges and opportunities. Journal of Applied Environmental and Biological Sciences 2(7), 329-335.

[6] Dhokhikah, Y., Trihadiningrum, Y., Sunaryo, S. (2015). Community participation in household solid waste reduction in Surabaya, Indonesia. Resources, Conservation and Recycling 102: 153-162.

[7] Friedberg E. and Hilderbrand, M. E. (2017) Observing policy-making in Indonesia. Springer Nature Singapore Pte Ltd, Singapore.

[8] Kaufman, S., M. (2012). "Quantifying sustainability: industrial ecology, materials flow and life cycle analysis" in Metropolitan Sustainability: 40-54. Woodhead Publishing Limited.

[9] Laner, D., Rechberger, H., Astrup, T. (2014). Systematic evaluation of uncertainty in material flow analysis. Journal of Industrial Ecology 18: 859-870.

[10] Pariatamby, A. and Tanaka, M. (2014). Municipal solid waste management in asia and the pasific island: challenges and strategic solutions. Singapore: Springer-Verlag.

[11] Sanitation Working Group Surabaya. (2010). Draft of sanitation Surabaya white book. Settlement Sanitation Development Acceleration Program (PPSP) (in Indonesian).

[12] Selomo, M., Birawida, A. B., Mallongi, A., Muammar. (2016). Waste bank as a solution in waste management in Makassar. Journal of Indonesian Public Health Media 12 (4): 232-240.

[13] Sembiring, E. and Nitivattananon, V. (2010). Sustainable solid waste management towards an inclusive society: Integration of the informal sector. Resources, Conservation and Recycling, 54: 802-809.

[14] Statistics Indonesia. (2019). Statistical year book of Surabaya (In Indonesian).

[15] Suryani, A. S. (2014). The role of waste banks in the effectiveness of waste management (case study of Malang waste bank). Information Data Study and Processing Center of the Secretariat General of the DPR RI.

[16] Tchobanoglous, G., Theisen, H. and Vigil, S. (1993). Integrated solid waste management: Engineering principles and management issues. McGraw-Hill, Inc. 